\title{
Penentuan Logam Cr(VI) Menggunakan Metoda Differensial Pulse Adsorptive Stripping Voltammetry dengan Calconcarboxylic Acid Sebagai Pengomplek
}

\section{Determination of Cr(VI) Metal Using Differential Pulse Adsorptive Stripping Voltametry Method with Calconcarboxylic Acid as Complexing}

\author{
Hilfi Pardi ${ }^{1}$; Nancy Willian ${ }^{1}$ \\ ${ }^{1}$ Department of Chemistry Education, Faculty of Teacher Training and Education Maritim Raja Ali Haji University
}

\section{A B S T R A K}

Penelitian ini menggunakan metode differential pulse adsorptive stripping voltammetry (DPAdSV) dengan elektroda merkuri tetesan gantung (HMDE) untuk menentukan logam $\mathrm{Cr}(\mathrm{VI})$ dengan Calconcarboxylic Acid (CCA) sebagai ligand dalam sampel air laut. Metode ini terjadi berdasarkan deposisi Logam-CCA pada elektroda merkuri pada periode waktu tertentu. Dengan menggunakan scan potensial kearah negatif dan voltammogram differential pulse akan menghasilkan voltammogram yang berbeda. Parameter instrumental dan kimia yang dapat meningkatan pegukuran diperoleh kondisi optimalnya antara lain, konsentrasi CCA 0,5 mM, pH 6, potensial deposisi $\left(\mathrm{E}_{\text {dep }}\right)-0,3 \mathrm{~V}$, waktu deposisi ( $\left.\mathrm{t}_{\text {dep }}\right) 60$ detik, konsentrasi buffer asetat $0,4 \mathrm{M}$, scan rate $150 \mathrm{mV} / \mathrm{s}$, tinggi pulse $90 \mathrm{mV}$, ukuran tetesan merkuri $4 \mathrm{~mm}^{2}$, Linieriti logam Cr (Ip vs konsentrasi) pada kisaran 5 sampai $200 \mu \mathrm{g} / \mathrm{L}$. Batas deteksi $\mathrm{Cr}(\mathrm{VI})$ adalah $0,23 \mu \mathrm{g} / \mathrm{L}$, standar deviasi relatif $0,24 \%$, recovery $98 \%$. Metode DPAdSV dengan CCA ligands untuk penentuan logam $\mathrm{Cr}(\mathrm{VI})$ sukses diaplikasikan pada sampel alam yaitu air laut dan air sungai.

\section{A B STRACT}

This study using differential pulse adsorptive voltammetry (DPAdSV) method with hanging drops mercury electrode to identification Cr(VI) metal and Calconcarbonxylic Acid (CCA) as a ligand in the sea and river water sample. This method occurs based on deposition CCA metal in the mercury electrode at a certain period. By using potential scanned to the negative direction and voltammogram differential pulse will result in a different voltammogram. The instrument and chemistry parameters which can increase the measurement was obtained optimal condition at concentration CCA $0.5 \mathrm{mM}, \mathrm{pH} 6$, potential deposition $\left(E_{\text {dep }}\right)-0,3 \mathrm{~V}$, time of deposition $\left(t_{d e p}\right) 60$ second, concentration of acetate buffer $0,4 \mathrm{M}$, scan rate $150 \mathrm{mV} / \mathrm{s}$, hight of pulse 90, $V$, number of drops mercury $4 \mathrm{~mm} 2$, metal linearity $\mathrm{Cr}$ (Ip vs concentration) about 5 to $200 \mu \mathrm{g} / \mathrm{L}$. Detection limit of $\mathrm{Cr}(\mathrm{VI})$ is $0,23 \mu \mathrm{g} / \mathrm{L}$, deviation standard relative $0,24 \%$, recovery $98 \%$. The DPAdSV method with CCA ligands to determine Cr(IV) metal, successful to applied at nature sample, it is seawater and river water.

Kata kunci/keyword:

Calconcarboxylic acid, Cromium(VI), diffrensial pulse, adsorptive stripping voltammetry

I N F O A R T I K E L

\begin{tabular}{l|l}
\hline Received: 17 Oct 2019; & $*$ coresponding author: hilfipardi@umrah.ac.id \\
$\begin{array}{l}\text { Revised:30 Oct 2019; } \\
\text { Accepted: } 11 \text { Nov 2019 }\end{array}$ & DOI: https://doi.org/10.22437/jisic.v11i2.7858
\end{tabular}




\section{PENDAHULUAN}

Pembuangan limbah industri dan pembuangan limbah rumah tangga, secara langsung atau tidak langsung ke perairan, menyebabkan perairan menjadi tercemar. Pencemaran diantaranya disebabkan oleh keberadaan logam berat, diantaranya $\mathrm{Pb}, \mathrm{Cd}$ dan $\mathrm{Cu}, \mathrm{Fe}, \mathrm{Cr}, \mathrm{Co}$, dan Ni (Giridhar, Kanchi, Niranjan, Bisetty, \& Naidu, 2014).

Logam $\mathrm{Cr}$ merupakan logam non essensial yang beracun pada konsentrasi rendah. Kromium $(\mathrm{Cr})$ adalah elemen logam yang sebagian besar ada di perairan, tanah, batuan, debu dan gas vulkanik. Keberadaan kromium di lingkungan terutama sebagai hasil dari aktivitas manusia melalui produksi limbah dan air buangan di industri pelapisan baja, penyamakan kulit dan pewarna dan dalam metalurgi (Arancibia, Nagles, Gómez, \& Rojas, 2012).

Menurut pedoman United States Environmental Protection Agency (EPA), standar air minum saat ini untuk kromium total di AS adalah $100 \mu \mathrm{g} / \mathrm{L}$ dari total kromium. Sehingga diperlukan metode yang sensitif dan selektif untuk penentuan logam Cr(VI) (Grabarczyk, Kaczmarek， \& Korolczuk, 2007).

Metode differensial pulse adsorptive stripping Voltammetri (DPAdSV) merupakan metoda yang unggul pada penggunaan sampel yang memiliki kadar garam tinggi, mempunyai sensitivitas tinggi serta selektivitas yang baik, batas deteksi yang rendah sehingga mampu mendeteksi hingga skala konsentrasi $\mu \mathrm{g} / \mathrm{L}$ atau $\mathrm{ng} / \mathrm{L}$, analisis cepat dan penyiapan sampel yang mudah, tahap prekonsentrasi yang cepat (kurang dari 60 detik) (Yardım, Gülcan, \& Zühre, 2013).

Calconcarboxylic Acid (CCA) berfungsi sebagai ligan yang dapat menyumbangkan lebih dari satu pasangan elektron bebasnya (hidroksil group) pada atom pusat (Gambar 1). Sehingga CCA dapat membentuk komplek dengan ion logam Cr(VI) (Amini \& Kabiri, 2005).

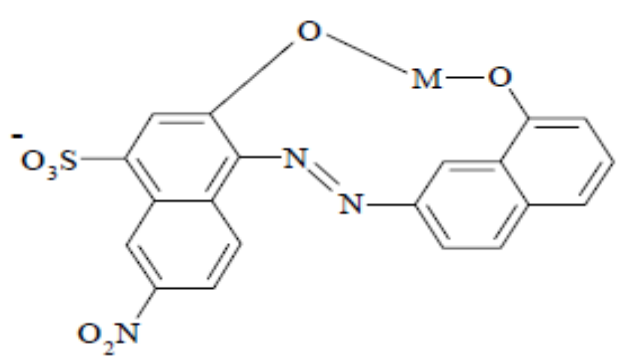

Gambar 1. Struktur Logam-CCA

Penelitian ini dilaporkan penggunaan CCA untuk penentuan logam $\mathrm{Cr}(\mathrm{VI})$ menggunakan elektroda merkuri tetesan gantung (HMDE) dalam metoda DPAdSV.

\section{METODE PENELITIAN}

\section{Alat dan Bahan}

DPAdSV ditentukan dengan a Metrohm 797 (Switdzeland), HMDE (elektroda kerja), $\mathrm{Ag} / \mathrm{AgCl} / \mathrm{KCl} 0,1 \mathrm{M}$ (elektroda pembanding), dan Pt (Elektroda pembantu), pH meter Metrohm (switdzeland), dan neraca analitis Mettler AE 200(USA), serta peralatan gelas yang biasa digunakan laboratorium.

Bahan yang digunakan pada penelitian ini adalah larutan induk $\mathrm{Cr}(\mathrm{VI})$ $1000 \mathrm{mg} / \mathrm{L}, \mathrm{NH}_{4} \mathrm{OH}$, Amonium asetat, asam asetat, aquabides, kalkon, $\mathrm{HNO}_{3} 65 \%$, sampel air laut dan air sungai, metanol, dan gas $\mathrm{N}_{2}$. Semua bahan merupakan analytical grade dari Merck. Sampel yang digunakan berasal dari air sungai Lubuk Minturun dan Muaro padang, kemudian sampel ditambahkan dengan $\mathrm{HNO}_{3} \quad 65 \%$ dengan perbandingan 1:1000.

\section{Pengukuran metoda Differensial pulse Adsorptive stripping voltammetry (AdSV)}

Sebanyak $10 \mathrm{~mL}$ larutan sampel ditambahkan 0,5 mL buffer asetat, 0,2 ml CCA, dimasukkan ke dalam voltammeter vessel. Larutan distirer dan purged dengan gas nitrogen selama 300 detik. Setelah HMDE baru dibentuk dilakukan proses adsorpsi Logam-CCA pada waktu dan potensial deposisi yang telah ditetapkan. Setelah resting 
selama 10 detik diffrential pulse voltammogram diperoleh. Kondisi voltammeter saat pengukuran Logam-CCA.

Set alat penentuan Logam-CCA pada sampel secara DPAdSV yaitu: Working electrode: HMDE, Calibration: Standard addition method, Number of replication: 4, Drop size: 5, Stirrer speed: $2000 \mathrm{rpm}$, mode: Differential pulse, Initial purge time: 300 detik, Addition purge time: 10 detik, potensial deposisi : -0,3 V, Waktu deposisi: 70 detik, Equallibration time: 10 detik, Pulse amplitude: 0,05 V, Start potential: $-0,8 \mathrm{~V}$, End potential: $-1,1 \mathrm{~V}$, Voltage step: 0,006 V, Voltage step time: 0,1 detik, Sweep rate: 0,06 V/detik, arus puncak Cr(VI): 0,4 V.

\section{HASIL DAN DISKUSI}

\section{Kondisi Optimum Pengukuran DPADSV}

\section{Pengaruh Calconcarboxilic Acid (CCA)}

Penelitian ini dilakukan Optimasi Penentuan logam Cr(VI) dengan DPAdSV menggunakan CCA sebagai pengomplek. Eksperimen awal yang dilakukan adalah penentuan kesesuaian CCA sebagai pengomplek dengan ion logam menggunakan HMDE. Gambar 2 menunjukkan voltammogram 0,5 mM CCA ( kurva a), ion logam $\mathrm{Cr}(\mathrm{VI}) 10 \mu \mathrm{g} / \mathrm{L}$ (kurva b), $10 \mu \mathrm{g} / \mathrm{L}$ ion logam $\mathrm{Cr}(\mathrm{VI})$ and 0,5 mM CCA (kurva c). Kurva (a) menunjukkan tidak adanya puncak yang dihasilkan CCA pada rentang potensial setengah ion logam $\mathrm{Cr}(\mathrm{VI})$ sehingga CCA tidak megganggu pembentukan arus puncak ion logam. Curve (b) menunjukkan arus puncak lebih kecil dibandingkan curve (c), hal itu menunjukkan dengan adanya CCA dapat meningkatkan arus puncak ion logam tereduksi pada HMDE sehingga dapat meningkatkan selektiviti dan sensitiviti metoda.

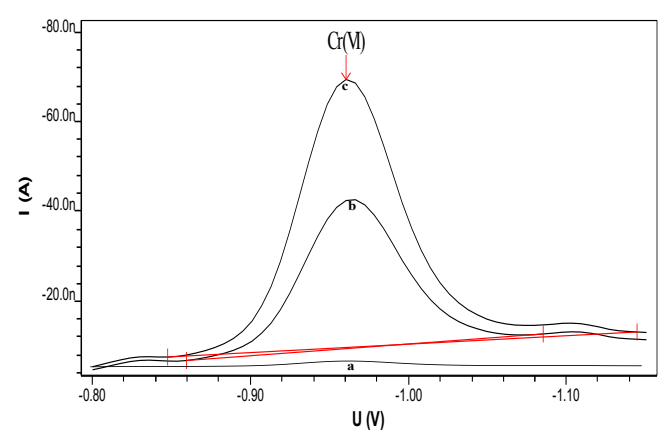

Gambar 2. Differential pulse voltammogram CCA (a); ion logam $\mathrm{Cr}(\mathrm{VI})$ (b); dan CCA + ion logam $\mathrm{Cr}(\mathrm{VI})$ (c). Kondisi pengukuran : larutan standar $\mathrm{Cr}(\mathrm{VI}) 10 \mu \mathrm{g} / \mathrm{L}$; CCA 0,5 $\mathrm{mM}$; buffer asetat $0,4 \mathrm{M}$; $\mathrm{pH}$ 6; potensial deposisi -0,3 Volt; waktu deposisi 60 detik; rentang scan rate $-0,8$ sampai $-1,1$ $\mathrm{V}$., scan rate $150 \mathrm{mV} / \mathrm{s}$, tinggi pulse 90 $\mathrm{mV}$, ukuran tetesan merkuri $5 \mathrm{~mm}^{2}$

\section{Pengaruh Variasi pH}

Pengaturan $\mathrm{pH}$ akan mempengaruhi kestabilan komplek Logam-CCA sehingga menghasilkan arus puncak yang berbeda setiap perubahan $\mathrm{pH}$. Optimasi penentuan $\mathrm{pH}$ larutan divariasikan mulai dari $\mathrm{pH} 3$ sampai pH 9 (Gambar 3).

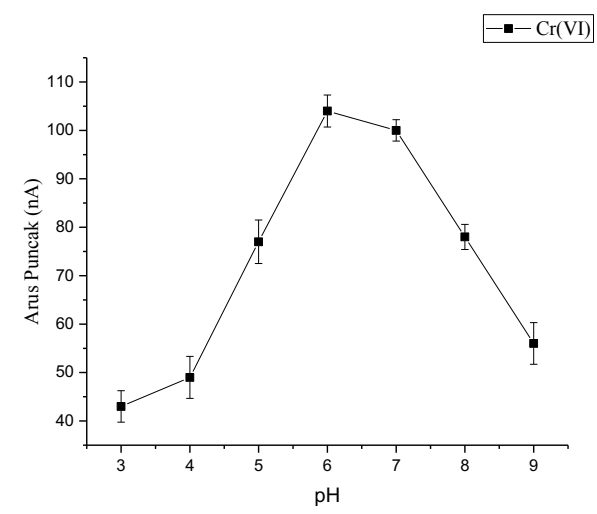

Gambar 3. Kurva hubungan variasi $\mathrm{pH}$ terhadap arus puncak (Ip). Kondisi pengukuran : larutan standar $\mathrm{Cr}(\mathrm{VI}) 10 \mu \mathrm{g} / \mathrm{L}$; CCA $0,5 \mathrm{mM}$; buffer asetat $0,4 \mathrm{M}$; potensial deposisi $-0,3$ Volt; waktu deposisi 60 detik; rentang scan rate $-0,8$ sampai $-1,1 \mathrm{~V}$., scan rate $150 \mathrm{mV} / \mathrm{s}$, tinggi pulse $90 \mathrm{mV}$, ukuran tetesan merkuri $5 \mathrm{~mm}^{2}$.

Penentukan $\mathrm{pH}$ larutan untuk menambah selektifitas dan melindungi zat yang akan dianalisis. pH 3 sampai 6 arus 
puncak yang didapatkan kecil karena kondisi larutan asam yang mengandung banyak $\mathrm{H}^{+}$ sehingga menyebabkan protonasi gugus hidroksil $\left(\mathrm{OH}^{-}\right)$pada $\mathrm{CCA}$. $\mathrm{pH}$ diatas 6 arus puncak yang didapatkan kecil disebabkan karena hidrolisis logam $\mathrm{Cr}$ (VI) menyebabkan gangguan pembentukan kompleks LogamCCA. Jadi pH lebih kecil dan lebih tinggi dari pH 6 menyebabkan kompleksasi metals dengan CCA akan berkurang (Jastrzebska, Karwowska, Olszyna, \& Kunicki, 2015). pH 6 dipilih untuk penentuan parameter berikutnya.

\section{Pengaruh Konsentrasi CCA}

Konsentrasi CCA yang digunakan yaitu $0,1 \mathrm{mM}$ sampai $0,9 \mathrm{mM}$ (Gambar 4).

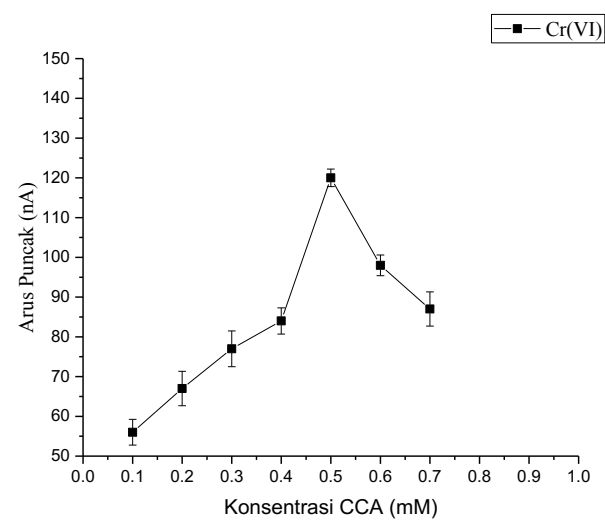

Gambar 4. Kurva hubungan konsentrasi kalkon (mM) terhadap arus puncak(Ip). Kondisi pengukuran : larutan standar $\mathrm{Cr}(\mathrm{VI}) 10$ $\mu \mathrm{g} / \mathrm{L}$; buffer asetat $0,4 \mathrm{M} ; \mathrm{pH} 6$; potensial deposisi -0,3 Volt; waktu deposisi 60 detik; rentang scan rate $-0,8$ sampai $-1,1 \mathrm{~V}$. , scan rate $150 \mathrm{mV} / \mathrm{s}$, tinggi pulse $90 \mathrm{mV}$, ukuran tetesan merkuri $5 \mathrm{~mm}^{2}$.

Arus puncak yang dihasilkan meningkat dengan meningkatnya konsentrasi CCA yang diberikan. Konsentrasi CCA kecil menghasilkan arus puncak yang kecil, karena masih ada ion logam yang tidak membentuk komplek dengan CCA. Pada konsentrasi CCA yang lebih besar yaitu diatas $0,5 \mathrm{mM}$ arus puncak yang dihasilkan menurun. Hal ini disebabkan karena komplek yang terbentuk stabil sehingga hanya sedikit komplek yang mengalami reduksi (Jugade \& Joshi, 2012). Hasil menunjukkan bahwa konsentrasi CCA
0,5 mM merupakan konsentrasi optimum, karena memberikan arus puncak yang lebih tinggi dan digunakan pada penentuan selanjutnya.

\section{Pengaruh konsentrasi elektrolit pendukung (buffer asetat)}

Elektrolit pendukung berfungsi untuk mengurangi tahanan larutan, efek migrasi ion, dan mempertahankan kekuatan ion agar tetap konstan. Elektrolit pendukung yang digunakan adalah buffer asetat $0,1 \mathrm{M}$ sampai 0,7 M (Gambar 5). Tinggi puncak tertinggi dicapai pada konsentrasi buffer asetat $0,4 \mathrm{M}$, hal ini terjadi karena pada konsentrasi tersebut tebentuk komplek Logam-CCA yang paling stabil dan paling banyak teradsopsi pada permukaan HMDE(Abbasi, Khodarahmiyan, \& Abbasi, 2011). Jadi konsentrasi buffer asetat $0,4 \mathrm{M}$ digunakan sebagai elektrolit pendukung untuk percobaan lebih lanjut.

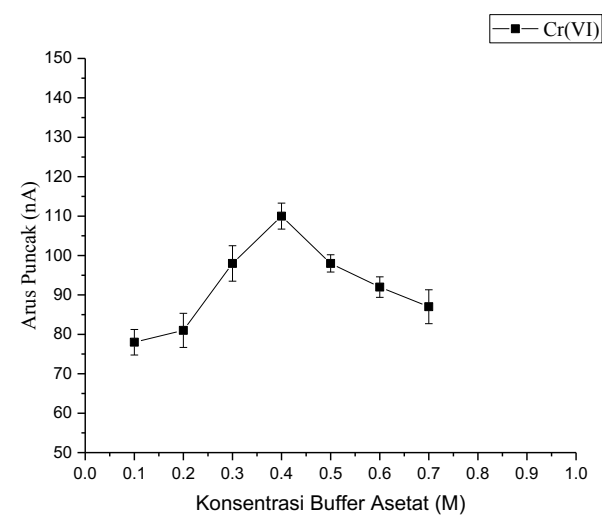

Gambar 5. Kurva hubungan potensial deposisi (-V) terhadap arus Puncak (Ip). Kondisi pengukuran : larutan standar $\mathrm{Cr}(\mathrm{VI}) 10$ $\mu \mathrm{g} / \mathrm{L}$; CCA $0,5 \mathrm{mM}$; $\mathrm{pH} 6$; potensial deposisi -0,3 Volt; waktu deposisi 60 detik; rentang scan rate $-0,8$ sampai $-1,1$ $\mathrm{V}$., scan rate $150 \mathrm{mV} / \mathrm{s}$, tinggi pulse 90 $\mathrm{mV}$, ukuran tetesan merkuri $5 \mathrm{~mm}^{2}$.

\section{Pengaruh Potensial deposisi $\left(\mathbf{E}_{\text {dep }}\right)$}

Variasi potensial deposisi ion logam Cr(VI) ditunjukkan Gambar 6. Diberikan potensial diantara elektroda kerja dan elektroda pembanding. Pada saat terjadinya 
reaksi, arus dilewatkan ke elektroda pembantu sehingga reaksi yang terjadi di elektroda pembantu berlawanan dengan reaksi yang terjadi di elektroda kerja. Gambar 6 menunjukkan pengaruh pemberian potensial terhadap arus puncak yang dihasilkan untuk optimasi potensial deposisi secara simultan, potensial yang diberikan dimulai dari $-0,1 \mathrm{~V}$ sampai $-0,7 \mathrm{~V}$. Saat awal pengukuran, arus puncak meningkat dengan semakin meningkatnya potensial kearah potensial negatif yang diberikan. Namun setelah potensial $-0.3 \mathrm{~V}$ arus puncak yang dihasilkan menurun. Hal ini disebabkan karena telah terjadi deposisi sempurna pada permukaan elektroda, dan terjadi stripping sehingga pada saat potensial meningkat kearah potensial negatif tidak ada lagi analit yang terdeposisi (Muñoz, Zúñiga, \& Arancibia, 2010). Data pengukuran memperlihatkan bahwa $E_{\text {dep }}$ optimum yaitu pada $-0,3 \mathrm{~V}$ yang digunakan untuk penentuan parameter selanjutnya.

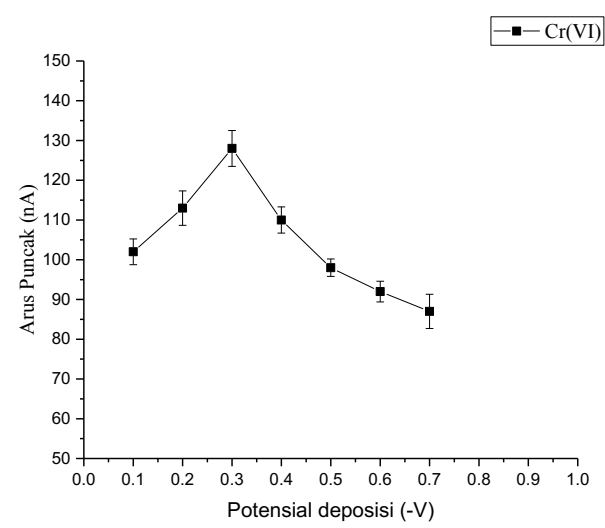

Gambar 6. Kurva hubungan potensial deposisi (-V) terhadap arus Puncak (Ip). Kondisi pengukuran : larutan standar $\mathrm{Cr}(\mathrm{VI}) 10$ $\mu \mathrm{g} / \mathrm{L}$; CCA 0,5 mM; buffer asetat $0,4 \mathrm{M}$; $\mathrm{pH}$ 6; waktu deposisi 60 detik; rentang scan rate $-0,8$ sampai $-1,1 \mathrm{~V}$., scan rate $150 \mathrm{mV} / \mathrm{s}$, tinggi pulse $90 \mathrm{mV}$, ukuran tetesan merkuri $5 \mathrm{~mm}^{2}$.

\section{Pengaruh waktu deposisi $\left(t_{d e p}\right)$}

Variasi waktu deposisi terhadap arus puncak ion logam $\mathrm{Cr}(\mathrm{VI})$ yang didapatkan menunjukkan semakin lama waktu yang diberikan maka semakin banyak analit yang terdeposisi ke permukaan elektroda sehingga sewaktu tahap stripping memberikan arus puncak yang tinggi.

Gambar 7 menunjukkan variasi $t_{\text {dep }}$ terhadap arus puncak. Waktu 30 detik menghasilkan arus puncak yang masih kecil, Hal ini disebabkan karena pada saat deposisi jumlah analit pada elektroda masih sedikit.Pemberian waktu yang lebih lama akan menyebabkan analit lebih banya terdeposisi pada elektroda kerja, tetapi terlalu lama bisa menyebakan elektroda kerja menjadi jenuh(Es, Khalili, Khazaeifar, \& Hossein, 2011). $t_{\text {dep }} 60$ detik menunjukkan arus paling tinggi, sehingga digunakan untuk penentuan parameter selanjutnya.

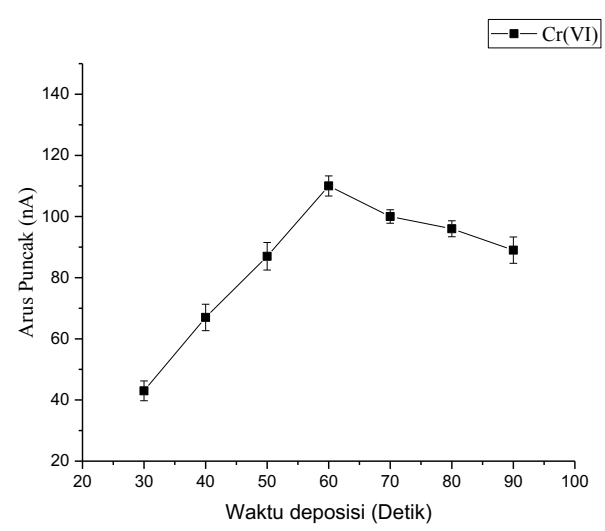

Gambar 7. Kurva hubungan waktu deposisi (detik) terhadap arus puncak (nA). Kondisi pengukuran : larutan standar $\mathrm{Cr}(\mathrm{VI}) 10$ $\mu \mathrm{g} / \mathrm{L}$; CCA $0,5 \mathrm{mM}$; buffer asetat $0,4 \mathrm{M}$; $\mathrm{pH}$ 6; potensial deposisi -0,3 Volt; rentang scan rate $-0,8$ sampai $-1,1 \mathrm{~V}$., scan rate $150 \mathrm{mV} / \mathrm{s}$, tinggi pulse $90 \mathrm{mV}$, ukuran tetesan merkuri $5 \mathrm{~mm}^{2}$.

\section{Pengaruh intrumental variables ( scan rate, pulse amplitude,ukuran tetesan merkuri, frequency)}

Meningkatkan sensitivitas penentuan Logam-CCA, pengaruh parameter voltametri differential pulse diselidiki. Scan rate (Gambar 8) dan pulse amplitude diselidiki pada kisaran $10 \mathrm{mV} / \mathrm{s}$ sampai $190 \mathrm{mV} / \mathrm{s}$ dan $0,1 \mathrm{~V} / \mathrm{s}$ sampai $0,9 \mathrm{~V} / \mathrm{s}$. Arus puncak LogamCCA meningkat dengan meningkatnya scan rate dan pulse amplitude,tetapi semakin tinggi akan membeuat voltammogram logam $\mathrm{Cr}$ (VI) 
semakin melebar sehingga membuat voltammogram saling tumpang tindih dan menyebabkan arus puncak logam menurun, oleh karena itu scan rate $150 \mathrm{mV} / \mathrm{s}$ dan pulse amplitude $0,8 \mathrm{~V} / \mathrm{s}$ yang dipilih. Ukuran tetesan merkuri yang diselidi adalah $0,25 \mathrm{~mm}^{2}$ sampai $4 \mathrm{~mm}^{2}$. Semakin besar ukuran ukuran tetesan merkuri semakin tinggi arus puncak logam, tetapi jika terlalu tinggi mercury akan jatuh sebelum proses reduksi logam berlangsung. Arus puncak Logam-CCA meningkat dengan peningkatan frequency dari 10 sampai $100 \mathrm{~Hz}$. Frequency 25 dipilih sebagai kondisi optimu, karena menunjukkan bentuk voltammogram yang simetris dan tidak melebar(Wang, 2006).

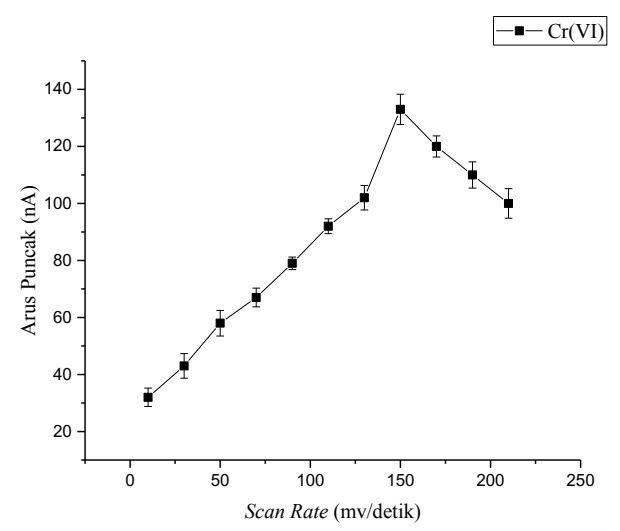

Gambar 8. Kurva hubungan scan rate (mV/detik) terhadap arus puncak (nA). Kondisi pengukuran : larutan standar $\mathrm{Cr}(\mathrm{VI}) 10$ $\mu \mathrm{g} / \mathrm{L}$; CCA 0,5 mM; buffer asetat 0,4 M; $\mathrm{pH}$ 6; potensial deposisi -0,3 Volt; waktu deposisi 60 detik; rentang scan rate $-0,8$ sampai -1,1 V, tinggi pulse $90 \mathrm{mV}$, ukuran tetesan merkuri $5 \mathrm{~mm}^{2}$.

\section{Parameter Analitik}

linieriti (Ip vs konsentrasi) logam Cr(VI) pada kisaran 5 sampai $2000 \mu \mathrm{g} / \mathrm{L}$ dan $\mathrm{R}^{2} 0.99658$ (Gambar 9). LOD dihitung menggunakan $(3 \times \mathrm{SD}) / m$, dimana SD standar deviasi dan $m$ adalah kemiringan kurva kalibrasi diperoleh $0,23 \mu \mathrm{g} / \mathrm{L}$. Penentuan ketepatan analitis metoda dihitung dari pengukuran 10 kali ulangan $(\mathrm{n}=10) 10 \mu \mathrm{g} / \mathrm{L}$ Cr(VI). SDR yang diperoleh adalah $0,24 \%$. Penentuan keakuratan dihitung nilai perolehan kembali sampel air laut sehingga diperoleh nilai recovery $\mathrm{Cr}$ (VI) $98 \%$.
Nilai SDR dan recovery yang baik digunakan menurut metoda standar AOAC untuk logam dengan konsentrasi $10 \mu \mathrm{g} / \mathrm{L}$ adalah dibawah $15 \%$ dan rentang $75 \%$ sampai $115 \%$, masing-masing (Work, 2002). Berdasarkan data yang diperoleh bahwa metoda ini dapat digunakan karena kecil dari amabang batas yang dianjurkan, dan memiliki ketelitian yang tinggi (Grabarczyk, 2008).

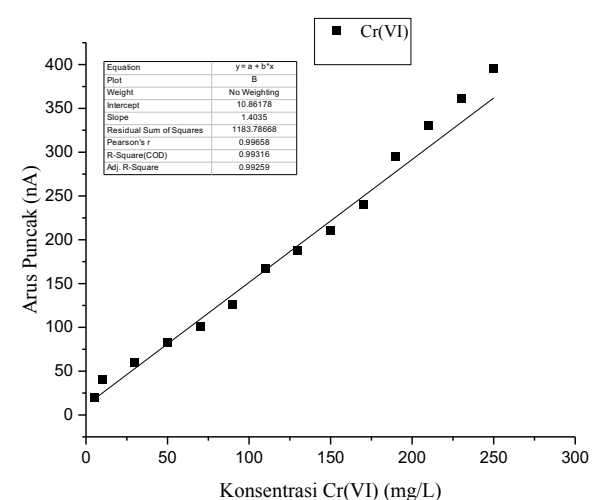

Gambar 9. Grafik hubungan konsentrasi Cr(VI) vs arus puncak (Ip)

\section{Gangguan kationik dan anionik}

Kemungkinan gangguan dari kationik dan anionik terhadap pengukuran logam $\mathrm{Cr}(\mathrm{VI})$ menggunakan metoda DPAdSV dengan CCA sebagai pengomplek ditentukan. Pengukuran dilakukan pada logam $\mathrm{Cr}(\mathrm{VI}) 10$ $\mu \mathrm{g} / \mathrm{L}$ menggunakan kondisi optimum yang telah diperoleh. Adapun kationik dan anionik yang diuji adalah $\mathrm{Cu}^{2+}, \mathrm{Ca}^{2+}, \mathrm{Ni}^{2+}, \mathrm{Co}^{2+}, \mathrm{Cr}^{3+}$, $\mathrm{Fe}^{3+}, \mathrm{Sr}^{2+}, \mathrm{K}^{+}, \mathrm{Na}^{+}, \mathrm{Li}^{+}, \mathrm{Al}^{3+}, \mathrm{Mn}^{2+}, \mathrm{Mg}^{2+}$, $\mathrm{NH}_{4}^{+}, \mathrm{Cl}^{-}, \mathrm{CO}_{3}{ }^{2-}, \mathrm{F}^{-}, \mathrm{Br}^{-}, \mathrm{ClO}_{4}^{-}, \mathrm{SCN}^{-}, \mathrm{NO}_{3}{ }^{-}$ konsentrasi yang diuji adalah $1 \mathrm{mg} / \mathrm{L}$ sampai $10 \mathrm{mg} / \mathrm{L}$. Hasil pengujian menunjukkan tidak adanya gangguan pengukuran $\mathrm{Cr}(\mathrm{VI})$ hingga konsentrasi $10 \mathrm{mg} / \mathrm{L}$ kationik dan anionik.

\section{Aplikasi pada Sampel alam}

Metoda DPAdSV yang telah diusulkan diaplikasikan pada sampel air laut (Gambar 10) dan air sungai. Metoda standar adisi digunakan untuk penentuan sampel untuk menghilangkan efek matrik. Seperti yang terlihat pada Table 1, konsentrasi tertinggi untuk logam $\mathrm{Cr}(\mathrm{VI})$ terdapat pada air 
laut yaitu $15,34 \pm 1,5 \mu \mathrm{g} / \mathrm{L}$. Berdasarkan batas minimum konsentrasi logam $\mathrm{Cr}(\mathrm{VI})$ air laut dan air sungai yang dideteksi berada di bawah yang diusulkan oleh EPA.

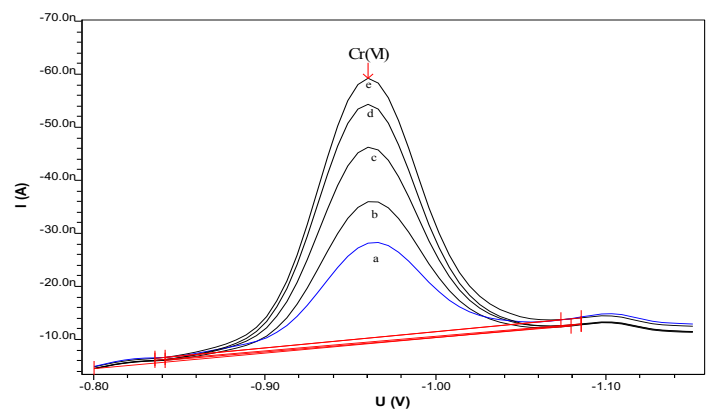

Gambar 10. Voltammogram logam Cr(VI) dalam sampel air laut (a), adisi standar $\mathrm{Cr}(\mathrm{VI})$ $5 \mu \mathrm{g} / \mathrm{L}$ (b sampai e).

Tabel 1. Penentuan logam $\mathrm{Cr}(\mathrm{VI})$ dalam sampel air laut dan air sungai dengan metoda DPAdSV

\begin{tabular}{lll}
\hline Sampel & \multicolumn{2}{c}{$\operatorname{Cr}(\mathrm{VI})(\mu \mathrm{g} / \mathrm{L})$} \\
\cline { 2 - 3 } & \multicolumn{1}{c}{ Air laut } & Air sungai \\
\hline I & $15,34 \pm 1,5$ & $5,1 \pm 1,5$ \\
II & $11,21 \pm 1,2$ & $3,22 \pm 0,9$ \\
III & $3,16 \pm 1,2$ & $1,44 \pm 1,5$ \\
\hline
\end{tabular}

keterangan:

$\mathrm{I}=$ permukaan tepi

$\mathrm{II}=$ permukaan tengah

\section{DAFTAR PUSTAKA}

Abbasi, S., Khodarahmiyan, K., \& Abbasi, F. (2011). Simultaneous determination of ultra trace amounts of lead and cadmium in food samples by adsorptive stripping voltammetry. Food Chemistry, 128(1), 254-257. Elsevier Ltd.

Amini, M. K., \& Kabiri, M. (2005). Iranian chemical society determination of trace amounts of nickel by differential pulse adsorptive cathodic stripping voltammetry using calconcarboxylic acid as a chelating agent, 2(1), 32-39.

Arancibia, V., Nagles, E., Gómez, M., \& Rojas, C. (2012). Speciation of Cr ( VI ) and $\mathrm{Cr}$ ( III ) in water samples by adsorptive stripping voltammetry in the presence of pyrogallol red applying a selective accumulation potential, 7 , 11444-11455.
$\mathrm{III}=$ kedalamam $>1 \mathrm{~m}$

\section{KESIMPULAN}

Metoda DPAdSV untuk penentuan logam $\mathrm{Cr}(\mathrm{VI})$ pada deposisi ligan CAC berhasil digunakan untuk penentuaan logam Cr(VI) pada konsentarsi trace pada sampel air laut. Metoda ini memiliki sensitivitas yang tinggi, selektivitas yang baik, tidak memakan biaya yang mahal, pengerjaannya cepat dengan kondisi optimum yang diperoleh sebagai berikut, konsentrasi CCA 0,5 mM, pH 6 , potensial deposisi $\left(E_{\text {dep }}\right)-0,3 \mathrm{~V}$, waktu deposisi $\left(t_{d e p}\right) 60 \mathrm{~s}$, konsentrasi buffer asetat $0,4 \mathrm{M}$, scan rate $150 \mathrm{mV} / \mathrm{s}$, tinggi pulse 90 $\mathrm{mV}$, ukuran tetesan merkuri $5 \mathrm{~mm}^{2}$. linieriti (Ip vs konsentrasi) pada kisaran 5 to $200 \mu \mathrm{g} / \mathrm{L}$. Batas deteksi $\mathrm{Cr}(\mathrm{VI})$ adalah $0.23 \mu \mathrm{g} / \mathrm{L}$. standar deviasi relatif $0,24 \%$, recovery $98 \%$.

Es, Z., Khalili, M., Khazaeifar, A., \& Hossein, G. (2011). Electrochimica acta simultaneous extraction and determination of lead, cadmium and copper in rice samples by a new preconcentration technique: Hollow fiber solid phase microextraction combined with differential pulse anodic stripping voltammetry, 56, 3139-3146.

Giridhar, C., Kanchi, S., Niranjan, T., Bisetty, K., \& Naidu, N. V. (2014). Sensitive determination of nickel ( II ) using catalytic hydrogen wave in the presence of dithiocarbamates at DME, 1(1), 1-6. 
Grabarczyk, M. (2008). Simultaneous extraction and catalytic adsorptive stripping voltammetric measurement of $\mathrm{Cr}$ ( VI ) in solid samples, 158, 491-498.

Grabarczyk, M., Kaczmarek, L., \& Korolczuk, M. (2007). Determination of $\mathrm{Cr}$ ( VI ) in the presence of complexing agents and humic substances by catalytic stripping voltammetry, (Vi), 1183-1188.

Jastrzebska, A. M., Karwowska, E., Olszyna, A. R., \& Kunicki, A. (2015). Influence of bacteria adsorption on zeta potential of $\mathrm{Al} 2 \mathrm{O} 3$ and $\mathrm{A} 12 \mathrm{O} 3 \mathrm{Ag}$ nanoparticles in electrolyte and drinking water environment studied by means of zeta potential. Surface and Coatings Technology, 271, 225-233.

Jugade, R. M., \& Joshi, A. P. (2012). Adsorptive cathodic stripping voltammetric determination of cadmium in environmental samples, 2(4), 246250 .
Muñoz, C., Zúñiga, M., \& Arancibia, V. (2010). Stripping voltammetric determination of cadmium in sea water using a carbon paste electrode modified with alginic acid from brown algae, 21(9), 1688-1691.

Wang, J. (2006). Analytical (3 ed.). New Jersey: John Wiley \& Sons, Inc.

Work, S. V. (2002). AOAC Guidelines for single laboratory validation of chemical methods for dietary supplements and botanicals.

Yardım, Y., Gülcan, M., \& Zühre, S. (2013). Determination of vanillin in commercial food product by adsorptive stripping voltammetry using a boron-doped diamond electrode, 141, 1821-1827. 